\title{
Experimental mineralization of crustacean eggs: new implications for the fossilization of Precambrian-Cambrian embryos
}

\author{
D. Hippler ${ }^{1}$, N. Hu ${ }^{1}$, M. Steiner ${ }^{2}$, G. Scholtz ${ }^{3}$, and G. Franz ${ }^{1}$ \\ ${ }^{1}$ Technische Universität Berlin, Department of Mineralogy, Sekr. ACK9, Ackerstrasse 76, 13355 Berlin, Germany \\ ${ }^{2}$ Freie Universität Berlin, Department of Earth Sciences, Malteserstrasse 74-100, Haus D, 12249 Berlin, Germany \\ ${ }^{3}$ Humboldt-Universität zu Berlin, Department of Biology, Comparative Zoology, Philippstrasse 13, 10115 Berlin, Germany
}

Correspondence to: D. Hippler (dorothee.hippler@tu-berlin.de)

Received: 15 November 2011 - Published in Biogeosciences Discuss.: 15 December 2011

Revised: 10 April 2012 - Accepted: 15 April 2012 - Published: 21 May 2012

\begin{abstract}
Phosphatized globular microfossils from the Ediacaran and lower Cambrian of South China represent an impressive record of early animal evolution and development. However, their phylogenetic affinity is strongly debated. Understanding key processes and conditions that cause exceptional egg and embryo preservation and fossilization are crucial for a reliable interpretation of their phylogenetic position. We conducted phosphatization experiments on eggs of the marbled crayfish Procambarus that indicate a close link between early mineralization and rapid anaerobic decay of the endochorional envelope. Our experiments replicated the different preservational stages of degradation observed in the fossil record. Stabilization of the spherical morphology was achieved by pre-heating of the eggs. Complete surface mineralization occurred under reduced conditions within one to two weeks, with fine-grained brushite $\left(\mathrm{CaHPO}_{4} \cdot 2 \mathrm{H}_{2} \mathrm{O}\right)$ and calcite. The mechanisms of decay, preservation of surface structures, and mineral replacement in the experiment were likely similar during fossilization of Cambrian embryos.
\end{abstract}

\section{Introduction}

Exceptional three-dimensional preservation of fossilized eggs and embryos from the Neoproterozoic, the Cambrian and the Ordovician provide direct insight into embryology during the eve of animal radiation (Bengtson and Zhao, 1997; Li et al., 1998; Xiao et al., 1998, 2000; Chen et al., 2004; Steiner et al., 2004a, b; Donoghue and Dong, 2005; Donoghue et al., 2006; Liu et al., 2007; Dong et al., 2010). In particular, the terminal Neoproterozoic Doushantuo For- mation (635 to $551 \mathrm{Ma}$; Condon et al., 2005) of South China has attracted considerable attention, first because fossilized algae and embryos occur in nearly rock-forming abundance, and second because radiometric ages of the Doushantuo Formation imply that the putative animal embryos predate the Precambrian-Cambrian boundary (542 Ma) by more than 20 million years. Although the interpretation of the Neoproterozoic phosphatized globular fossils as metazoan embryos has been doubted (Bailey et al., 2007a, b; Donoghue, 2007; Huldtgren et al., 2011), the latter finding would be consistent with hypotheses based on molecular clocks indicating that the last common ancestor of Metazoa appeared in the Neoproterozoic between 676 and $766 \mathrm{Ma}$ (Peterson et al., 2005, 2008). Regardless of the biological assignment of these microfossils it is remarkable that delicate organic cell structures can be replicated by earliest diagenetic phosphate formation operating at a high spatial and temporal resolution.

Undoubted fossilized animal eggs and embryos from the Cambrian, for instance of the early Cambrian Kuanchuanpu biota (Figs. 1a-c, 2), are mainly preserved as diagenetically phosphatized encrustations and impregnations in limestone (Xiao and Knoll, 1999; Steiner et al., 2004a; Hubert et al., 2005) and exhibit an extraordinary preservation of cell geometry and cytological structure. However, the classification and preservational context (taphonomy) of most of these fossils is still subject of extensive research. In the Ediacaran Doushantuo embryos, primarily the very earliest cleavage stages have been recovered, leading to the suggestion that the palaeo-embryological record may have strong biases on preserved developmental stages (Dornbos et al., 2005; Raff et al., 2006). Furthermore, an alternative interpretation of 

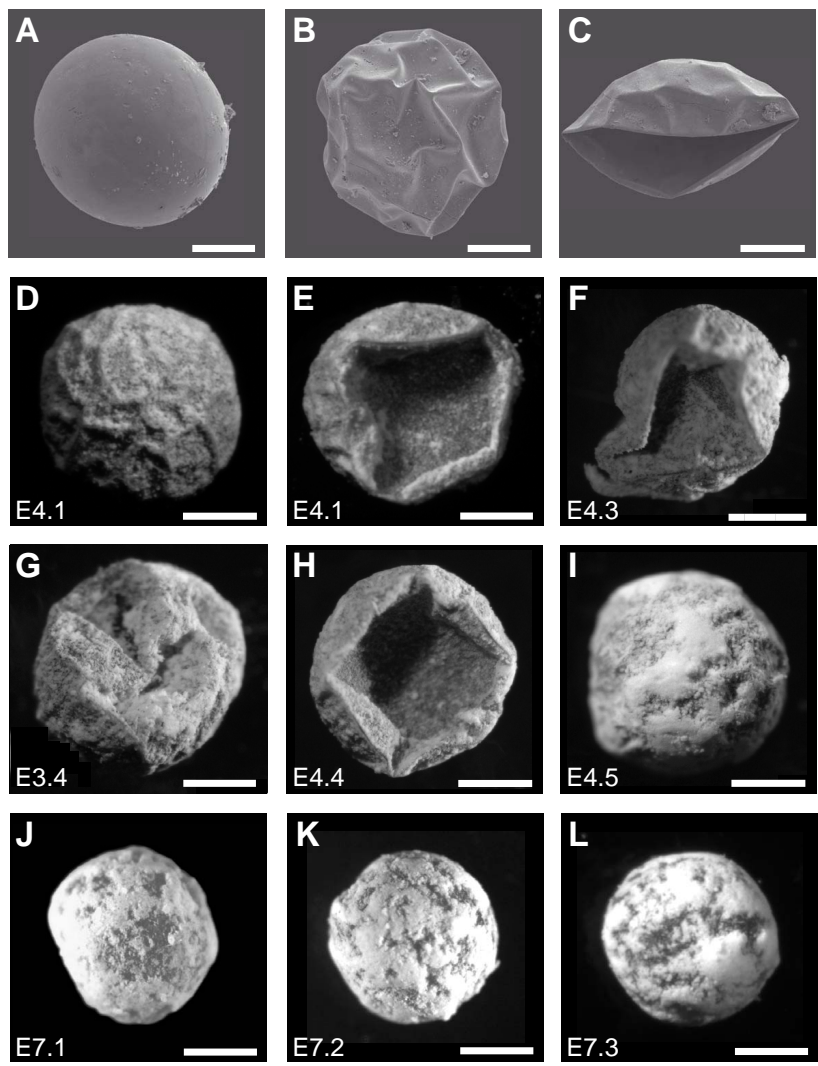

Fig. 1. Morphology preservation and mineralization of embryos. (A)-(C) Scanning electron micrographs of phosphatic embryo fossils from the lower Cambrian Kuanchuanpu fauna, China, and (D)(L) light microscope micrographs of experimentally mineralized embryos of the marbled crayfish Procambarus fallax f. virginalis. (A) Smooth egg of Olivooides multisulcatus. (B) Polygonal shrinkage pattern on fossil egg. (C) Fossil embryo displaying physical degradation. (D), (E) Experimentally mineralized embryo after 1 week, showing subtle surface mineralization, polygonal shrinkage pattern, and hemispherical internal collapse. (F) Completely mineralized and shrunken embryo after 3 weeks, and (G), (H) after 4 weeks. (I) Dense crystal accumulations appear after 5 weeks. (J)(L) Pre-heated crayfish embryos retain their globular morphology and exhibit complete mineralization of the outer membrane after 1 , 2 and 3 weeks (scale bar: (A) and (B) $=200 \mu \mathrm{m} ;(\mathbf{C})=300 \mu \mathrm{m}$; (D) $(\mathbf{L})=500 \mu \mathrm{m}$; and E4.1, E4.3, etc. $=$ experiment number $)$.

these microfossils was introduced suggesting that some putative fossil animal eggs and embryos, such as Megasphaera inornata and Parapandorina, represent solitary and reductively dividing giant vacuolated sulphur bacteria (Bailey et al., 2007a, b). This intriguing reinterpretation was questioned by Huldtgren et al. (2011), who demonstrated that the developmental patterns of most globular fossils have features incompatible with both multicellular metazoans embryos and giant bacteria. The authors concluded that these fossils were neither animals nor embryos, but show highest affinity within nonmetazoan holozoans or even more distant eukaryote branches.

To understand the fossil record of early metazoan evolution, the mechanism of decay and soft-tissue preservation has been studied by taphonomic analyses, in which the conditions of decay and mineralization were explored experimentally (Briggs, 1995, 2003). Previous experimental studies investigating the controls on the formation of authigenic minerals in association with decaying organic matter reported phosphatization of muscle tissue within weeks to a few months. This phosphatization was associated with a drop in the oxygen level and $\mathrm{pH}$, after the introduction of an anaerobic bacterial community and/or sea floor sediment to shrimp carcasses (Briggs and Kear, 1993a, 1994; Sagemann et al., 1999). The precipitation of either calcium phosphate or calcium carbonate is thereby related to local $\mathrm{pH}$ changes, with calcium phosphate being favored as $\mathrm{pH}$ decreases from neutral to acidic (Briggs and Wilby, 1996). Only a few studies have noted the experimental mineralization of invertebrate eggs. Experimental phosphatization of eggs was first reported from the shrimp Palaemon elegans, which was subjected to decay as a complete animal for 20 weeks (Briggs and Kear, 1993a). Later studies, which focused on the eggs, demonstrated that it was possible to maintain the external shape of Homarus gammarus, Limulus polyphemus, and Nephrops norvegicus egg cases for at least a year, including surface mineralization mainly as calcium carbonate or as a combination of calcium carbonate and calcium phosphate (Martin et al., 2003, 2005). Laboratory decay experiments also achieved the replication of the outer morphology of $H$. gammarus eggs by coating the eggs with pre-existing clay minerals in the presence of metabolizing bacteria (Martin et al., 2004).

None of these studies considered the effects of inherent fragility on the internal morphology and histology of invertebrate eggs. In normal seawater, freshly killed embryos are generally prone to rapid decomposition within a few hours. Embryo preservation for a prolonged time prior to mineralization is thus rather unlikely. Recent studies focused on the factors, which affect the decay and preservation of the earliest stages on embryonic and larvae development (Gostling et al., 2008, 2009; Raff et al., 2006, 2008). Four stages of decay can be distinguished (Gostling et al., 2008): (a) The onset of autolysis, (b) some shrinkage within the fertilization envelope, enzymatic breakdown of the cyctoplasm and coalescence of sub-cellular lipids, often associated with the degradation of cell structures through the activity of endogenous and exogenous microbes (cf. Raff et al., 2006), (c) continued degradation of cell structures and breakdown of the fertilization envelope, (d) generation of amorphous organic matter due to the total breakdown of subcellular material. Embryo fossilization can be attributed to three processes (Raff et al., 2008): (a) The rapid blockage of autolysis within an anaerobic environment, (b) bacterial invasion and consumption of the embryo, forming a replica that retains cell organization 

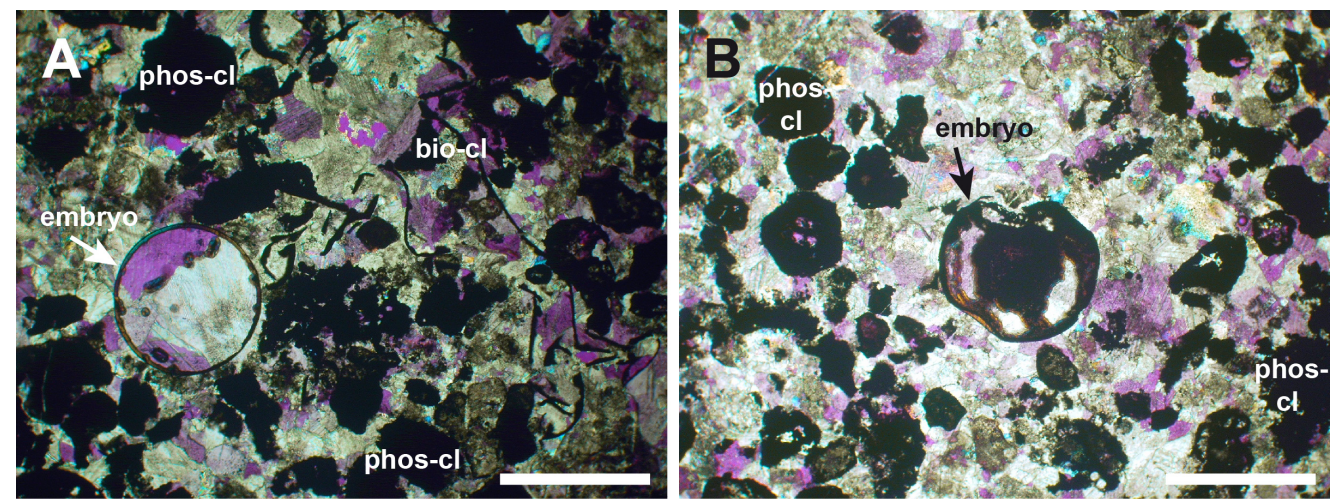

Fig. 2. Thin section photomicrographs (crossed polarized light) of an embryo-bearing layer, Kuanchuanpu section, China. (A) Phosphatized globular embryo fossil associated with phosphatic clasts and bioclasts in a coarse sparitic carbonate matrix. The embryo is preserved as a hollow cast cemented by carbonate. (B) Slightly collapsed and phosphatized embryo fossil partially filled with diagenetic calcium phosphate (scale bar: $600 \mu \mathrm{m}$ ).

and morphology, and (c) bacterial development of microenvironments inducing changes in embryo chemistry and mineralization potential.

Here, we report a succession of phosphatization experiments on eggs of the parthenogenetic crayfish Procambarus fallax $\mathrm{f}$. virginalis (Martin et al., 2010), in order to elucidate alternative scenarios for embryo fossilization. We intentionally followed a reductionist approach. We broke the complex natural conditions down to an inorganic two-component system consisting of calcite + phosphoric acid. These two components represented the environment for the co-existing organic material. We investigated the conditions that promote both the mineralization of invertebrate eggs as well as decay and preservation of organic tissue over a prolonged period of time under non-marine laboratory conditions. Our results show that experimental mineralization of invertebrate eggs can produce different qualities of preservation, which were similar in appearance to the documented fossil record.

\section{Material and methods}

\subsection{Sample material}

Eggs of Procambarus fallax f. virginalis (Fig. 3a; Martin et al., 2010) were taken from living animals that were kept in culture. Its capability, high fertility, fast growth, unisexuality and isogenic progeny (Scholtz et al., 2003; Martin et al., 2007) have made this species useful for physiological, ecological, evolutionary and genetic studies. Crayfish eggs, as those of decapod crustaceans in general, are encased by an inner vitelline membrane and a chorion (Winnicki et al., 2004) although the exact sequence and number of layers and their origin is debated (Cheung, 1966). The eggs are rich in yolk and reach diameters up to approximately $1000 \mu \mathrm{m}$. The stages of the specimens used in the experiments were de-
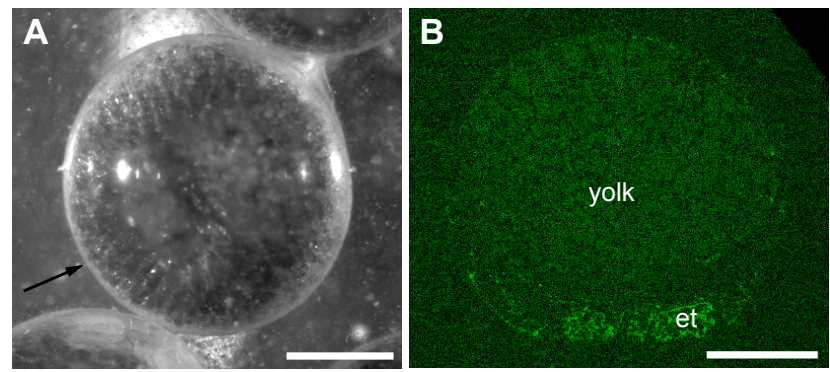

Fig. 3. (A) Photomicrograph of fresh egg of the marbled crayfish Procambarus fallax f. virginalis. Black arrow points to the translucent endochorion covering the yolk and the embryonic tissue. (B) SEM X-ray mapping of $P$ of a sliced untreated crayfish egg illustrating the original uniform $\mathrm{P}$ distribution for the yolk, whereas the embryonic tissue (et) of the germ area shows elevated $\mathrm{P}$ content (scale bar: $\mathbf{A}=500 \mu \mathrm{m} ; \mathbf{B}=400 \mu \mathrm{m}$ ).

termined according to the system developed by Alwes and Scholtz (2006).

\subsection{Experimental design}

Phosphatization experiments (E1 to E7, Table 1) were conducted in an exsiccator at room temperature and atmospheric pressure under different redox and $\mathrm{pH}$ conditions. Prior to the experiments, the eggs were stored in tapwater-filled glass vials at $9 \pm 1{ }^{\circ} \mathrm{C}$.

In all experiments, crustacean eggs were transferred to petri dishes loaded with mixture of $2.8 \mathrm{~g}$ of powdered analytically-grade synthetic calcite $\left(\mathrm{CaCO}_{3}\right), 0.5$ and accordingly $17 \mathrm{ml}$ phosphoric acid $\left(\mathrm{H}_{3} \mathrm{PO}_{4}, 85 \%\right), 2.5 \mathrm{ml}$ distilled water and $0.02 \mathrm{~g}$ of powdered activated carbon (the latter only in E3). This embedding medium is highly viscous and has a gel-like appearance. According to Eq. (1) finegrained brushite crystals $\left(\mathrm{CaHPO}_{4} \cdot 2 \mathrm{H}_{2} \mathrm{O}\right)$ formed, which was verified by $\mathrm{X}$-ray powder diffraction (Table 2 ). 
Table 1. Phosphatization experiments performed and corresponding conditions and duration.

\begin{tabular}{|c|c|c|c|c|c|c|c|c|c|}
\hline Species & Experiment & $\begin{array}{l}\text { Number of } \\
\text { embryos }\end{array}$ & $\begin{array}{c}\mathrm{CaCO}_{3} \\
{[\mathrm{~g}]}\end{array}$ & $\begin{array}{c}\mathrm{H}_{3} \mathrm{PO}_{4} \\
{[\mathrm{ml}]}\end{array}$ & $\begin{array}{l}\mathrm{H}_{2} \mathrm{O} \\
{[\mathrm{ml}]}\end{array}$ & $\begin{array}{c}\mathrm{C}_{\mathrm{act}} \\
{[\mathrm{g}]}\end{array}$ & Atmosphere & $\begin{array}{c}\text { Pre-heating } \\
\text { at } 80^{\circ} \mathrm{C} \pm 1^{\circ} \mathrm{C}\end{array}$ & $\begin{array}{c}\text { Duration } \\
\text { [days] }\end{array}$ \\
\hline Procambarus fallax & E1a & 1 & 2.75 & 17.0 & 2.5 & & air & & 15 \\
\hline \multirow[t]{19}{*}{ f. virginalis } & E1b & 1 & 2.80 & 0.5 & 2.5 & & air & & 6 \\
\hline & $\mathrm{E} 2 \mathrm{a}$ & 1 & 2.75 & 17.0 & 2.5 & & $\mathrm{~N}_{2}$ & & 15 \\
\hline & $\mathrm{E} 2 \mathrm{~b}$ & 1 & 2.80 & 0.5 & 2.5 & & $\mathrm{~N}_{2}$ & & 15 \\
\hline & E3.1 & 2 & 2.80 & 0.5 & 2.5 & 0.02 & $\mathrm{~N}_{2}$ & & 7 \\
\hline & E3.2 & 1 & 2.80 & 0.5 & 2.5 & 0.02 & $\mathrm{~N}_{2}$ & & 14 \\
\hline & E3.3 & 1 & 2.80 & 0.5 & 2.5 & 0.02 & $\mathrm{~N}_{2}$ & & 21 \\
\hline & E3.4 & 2 & 2.80 & 0.5 & 2.5 & 0.02 & $\mathrm{~N}_{2}$ & & 28 \\
\hline & E3.5 & 1 & 2.80 & 0.5 & 2.5 & 0.02 & $\mathrm{~N}_{2}$ & & 35 \\
\hline & E3.6 & 1 & 2.80 & 0.5 & 2.5 & 0.02 & $\mathrm{~N}_{2}$ & & 44 \\
\hline & E4.1 & 1 & 2.80 & 0.5 & 2.5 & & $\mathrm{~N}_{2}$ & & 7 \\
\hline & $\mathrm{E} 4.2$ & 2 & 2.80 & 0.5 & 2.5 & & $\mathrm{~N}_{2}$ & & 14 \\
\hline & $\mathrm{E} 4.3$ & 1 & 2.80 & 0.5 & 2.5 & & $\mathrm{~N}_{2}$ & & 21 \\
\hline & E4.4 & 1 & 2.80 & 0.5 & 2.5 & & $\mathrm{~N}_{2}$ & & 28 \\
\hline & E4.5 & 2 & 2.80 & 0.5 & 2.5 & & $\mathrm{~N}_{2}$ & & 35 \\
\hline & E4.6 & 4 & 2.80 & 0.5 & 2.5 & & $\mathrm{~N}_{2}$ & & 44 \\
\hline & E6.1 & 4 & 2.80 & 0.5 & 2.5 & & $\mathrm{~N}_{2}$ & yes & 7 \\
\hline & E7.1 & 2 & 2.80 & 0.5 & 2.5 & & $\mathrm{~N}_{2}$ & yes & 8 \\
\hline & E7.2 & 3 & 2.80 & 0.5 & 2.5 & & $\mathrm{~N}_{2}$ & yes & 14 \\
\hline & E7.3 & 3 & 2.80 & 0.5 & 2.5 & & $\mathrm{~N}_{2}$ & yes & 21 \\
\hline
\end{tabular}

All experiments were performed at room temperature and atmospheric pressure. Experiment E6 was discontinued after one week because of a leaky exsiccator.

Table 2. Phase fractions, lattice constants and statistical parameters of XRD-Rietveld refinement of experimental series E7.

\begin{tabular}{|c|c|c|c|c|c|c|c|c|c|c|c|c|c|c|c|c|}
\hline Sample & $\begin{array}{l}\text { Mineral } \\
\text { phase }\end{array}$ & $\begin{array}{l}\text { wt.- } \\
\%\end{array}$ & $\begin{array}{c}\mathrm{a} \\
{[\AA]}\end{array}$ & $2 \sigma$ & $\begin{array}{c}\mathrm{b} \\
{[\AA]}\end{array}$ & $2 \sigma$ & $\begin{array}{c}\mathrm{c} \\
{[\AA]}\end{array}$ & $2 \sigma$ & $\begin{array}{c}\alpha \\
{\left[{ }^{\circ}\right]}\end{array}$ & $\begin{array}{c}\beta \\
{\left[^{\circ}\right]}\end{array}$ & $2 \sigma$ & $\begin{array}{c}\gamma \\
{\left[{ }^{\circ}\right]}\end{array}$ & $\begin{array}{c}\mathrm{V} \\
{\left[\AA^{3}\right]}\end{array}$ & $2 \sigma$ & DW & $\chi^{2}$ \\
\hline \multirow[t]{2}{*}{ E $7.1 \mathrm{ebm}$} & brushite & 52 & 5.810 & 1 & 15.184 & 4 & 6.238 & 1 & 90 & 116.3 & 1 & 90 & 493.1 & 2 & 1.279 & 1.267 \\
\hline & calcite & 48 & 4.995 & 1 & 4.995 & 1 & 17.042 & 4 & 90 & 90 & & 120 & 368.3 & 1 & & \\
\hline \multirow[t]{2}{*}{ E $7.2 \mathrm{ebm}$} & brushite & 50 & 5.812 & 1 & 15.189 & 3 & 6.241 & 1 & 90 & 116.3 & 1 & 90 & 493.6 & 7 & 1.162 & 1.394 \\
\hline & calcite & 50 & 4.997 & 1 & 4.997 & 1 & 17.047 & 3 & 90 & 90 & & 120 & 368.6 & 1 & & \\
\hline \multirow[t]{2}{*}{ E $7.2 \mathrm{sc}$} & brushite & 55 & 5.812 & 1 & 15.173 & 4 & 6.241 & 1 & 90 & 116.3 & 1 & 90 & 493.1 & 2 & 1.201 & 1.360 \\
\hline & calcite & 45 & 4.996 & 4 & 4.996 & 4 & 17.044 & 2 & 90 & 90 & & 120 & 368.4 & 7 & & \\
\hline \multirow[t]{2}{*}{ E $7.3 \mathrm{ebm}$} & brushite & 47 & 5.812 & 1 & 15.187 & 3 & 6.240 & 1 & 90 & 116.3 & 1 & 90 & 493.4 & 7 & 1.319 & 1.204 \\
\hline & calcite & 53 & 4.997 & 1 & 4.997 & 1 & 17.046 & 3 & 90 & 90 & & 120 & 368.6 & 1 & & \\
\hline \multirow[t]{2}{*}{ E $7.3 \mathrm{sc}$} & brushite & 62 & 5.810 & 11 & 15.192 & 4 & 6.234 & 9 & 90 & 116.4 & 1 & 90 & 492.7 & 16 & & \\
\hline & calcite & 38 & 4.996 & 4 & 4.996 & 4 & 17.046 & 9 & 90 & 90 & & 120 & 368.4 & 6 & 0.056 & 2.956 \\
\hline
\end{tabular}

ebm = embedding medium; sc = surface crystallites; V = volume; DW = Durbin Watson factor

$\mathrm{CaCO}_{3}+\mathrm{H}_{3} \mathrm{PO}_{4}+\mathrm{H}_{2} \mathrm{O} \rightarrow \mathrm{CaHPO}_{4} \cdot 2 \mathrm{H}_{2} \mathrm{O}+\mathrm{CO}_{2} \uparrow$

Experimental series E1 and E2 were conducted to explore the effect of differences in the composition of the embedding medium on embryo preservation and mineralization. Experiment E1 took place under normal air, whereas experiment E2 proceeded under $\mathrm{N}_{2}$-atmosphere. Experimental series E3 to E7 were successively performed to study the progress of preservation and mineralization, applying the excess $\mathrm{CaCO}_{3}$ medium under $\mathrm{N}_{2}$-atmosphere. For this purpose, one to four embryos were removed from the experiment every week. After removal of the sampled specimens the exsiccator was refilled with $\mathrm{N}_{2}$. The duration of these experiments was generally between seven and 44 days. In order to reduce oxidation processes, and thus the decay process of the embryo tissue, powdered activated carbon was added to the sample surfaces in experimental series E3. To explore whether and 
how initial heating might stabilize the eggs and prevent them from collapsing during fossilization, experiments E6 and E7 were conducted; crustacean embryos were initially heated in distilled water at $80 \pm 1{ }^{\circ} \mathrm{C}$ for approximately five minutes.

\subsection{Sample preparation}

For scanning electron microscopy, the crayfish eggs were first dehydrated in ethanol. Then they were either dried at the critical point (using a Balzer dryer CPD 030) and mounted on stubs with adhesive tape or prepared in histological blocs. They were infiltrated overnight in a basic solution of $100 \mathrm{ml}$ Technovit ${ }^{\circledR} 7100$ and a hardener and subsequently filled in histo-moulds. Histoblocs were then prepared with Technovit ${ }^{\circledR} 3040$ and coated with silver and carbon.

For histological sections, the ethanol-dehydrated samples of experimental series E7 were infiltrated with a 1:1 mixture of araldite epoxy resin and epoxy propane overnight and subsequently transformed to solely araldite for one hour. Samples were then transferred to an araldite-loaded embedding mould and stationed till polymerisation at $70^{\circ} \mathrm{C}$ overnight. Histological sections were trimmed applying a rotation microscope (HM 350, Micron), cut into semi-thin sections $(2 \mu \mathrm{m})$ and transferred to slides. Histological sections of experimental series E7 were stained with toluidin blue $(0.5 \%)$ solution.

\subsection{Analytical techniques}

The mineralogical composition of the embedding medium was determined with a Philips PW1729 X-ray diffractometer at the Department of Mineralogy and Petrology of the Technical University Berlin. The device is equipped with a PW1050 goniometer, a Cu-tube with a Ni-filter, a secondary monochromator unit, and a scintillation counter (LiF doped with $\mathrm{Tl}$ ), operated at $40 \mathrm{kV} / 20 \mathrm{~mA}$. Measurements were conducted with the mean $\mathrm{K} \alpha$-beam $([\mathrm{K} \alpha 1+\mathrm{K} \alpha 2] / 2)$ at $1.5419 \AA$ between $5-80^{\circ}(2 \theta)$. Measurement time per scan (step size $0.02^{\circ}$ ) was $2 \mathrm{~s}$. Samples were ground in an agate mortar by adding acetone and spread on a silica-sampling holder. Data were evaluated with the software packages X'Pert High Score and Origin.

The mineralogical composition for the experimental series E7 was analyzed with a fully-automated STOE STADI $\mathrm{P}$ X-ray powder diffractometer, equipped with a primary monochromator unit and a $7^{\circ}$-position detector (Gottschalk et al., 1998) at the GeoForschungsZentrum Potsdam, operated at $40 \mathrm{kV} / 40 \mathrm{~mA}$. Measurements were conducted with a K $\alpha 1$-beam between $5-125^{\circ}(2 \theta)$. The step size was $0.1^{\circ}$ and the measurement time was 5-20 s. Samples were ground in an agate mortar and mixed with Elmers white glue, superimposed on a plastic film, which was transferred to a transmission-sampling holder. Mineralized eggs were directly glued on the plastic film. Structural parameters were refined using the software package GSAS for Rietveld analyses.

Calcium and $\mathrm{P}$ content of fresh crayfish eggs were determined on a Varian (Vista-MPX) inductively coupled plasma-atomic emission spectrometer (ICP-AES) at the GeoForschungsZentrum Potsdam. Eggs were taken from mother animals during cell devision stage 5-6 (after Alwes and Scholtz, 2006). They were oven-dried at $105^{\circ} \mathrm{C}$ for $24 \mathrm{~h}$. Dried embryos were put in Savillex ${ }^{\circledR}$ beakers which were filled with $10 \mathrm{ml}$ of quartz-distilled ultra pure water, for five hours at room temperature. After rinsing of the embryos two times with ultra pure water, they were dried on a hot plate at $120^{\circ} \mathrm{C}$ overnight for dry weight determination. About $2 \mathrm{ml}$ of $7 \mathrm{~N} \mathrm{HNO}_{3}$ was added to the dry mass, which was then vaporized on a hot plate at $160^{\circ} \mathrm{C}$ overnight. Since parts of the dried residues were not completely dissolvable, the $7 \mathrm{~N}$ $\mathrm{HNO}_{3}$ step was repeated three times. For chemical analysis, another $2 \mathrm{ml}$ of $1 \mathrm{~N} \mathrm{HNO}_{3}$ was finally added to the yellowish solution.

A Zeiss stereoscope (Stemi SV11) equipped with a Zeiss digital camera (AxioCam HRc) was used to examine the surfaces of the samples. In order to map the topography and determine the mineralogical and chemical composition of the samples, eggs were investigated using scanning electron microscopy (SEM images with a Hitachi S-2700 instrument, equipped with a tungsten cathode, operated at $20 \mathrm{kV} / 500 \mathrm{nA}$, and a Hitachi S-4000, equipped with a field emission cathode, operated at $20 \mathrm{kV} / 150 \mathrm{pA}$ ) at ZELMI, Technical University Berlin. Element determination was done applying an EDX system. The detection limit for measured elements was 0.1 weight-\%. Backscattered electron (BSE) and secondary electron (SE) images, as well as X-ray mappings were used to distinguish between organic matter and the mineralizing phases.

\section{Results}

We both determined and localized the initial $\mathrm{Ca}$ and $\mathrm{P}$ content of fresh crayfish eggs (Table 3). The dry mass contained $120 \mathrm{ppm} \mathrm{Ca}$ and 1.3 wt.-\% P, comparable to concentrations described for other invertebrate eggs (Martin et al., 2005). Scanning electron microscopic (SEM) mapping of $\mathrm{P}$ of an untreated egg in cross-section furthermore revealed an almost uniform distribution of $\mathrm{P}$, however with higher initial $\mathrm{P}$ concentrations in the embryonic tissue of the germ area and in some areas of marginal embryonic tissue (Fig. 2b).

Treatments with excess $\mathrm{H}_{3} \mathrm{PO}_{4}$ (experiment E1a und E2a, Table 1) preserved fresh crayfish eggs neither in an oxygenated (air) nor in $\mathrm{N}_{2}$ atmosphere. A few minutes after embedding the dark brown to black embryos turned red, and tiny blebs occurred on the egg's envelope. After two weeks, the eggs decomposed and orange lipid droplets leached into the embedding medium. 
Table 3. Comparison of initial phosphorus and calcium concentrations, occurrence of mineralization and embryo preservation in this and previous studies.

\begin{tabular}{|c|c|c|c|c|c|}
\hline Species & Reference & $\begin{array}{l}\mathrm{P} \text { [wt-\%] } \\
\text { dry mass }\end{array}$ & $\begin{array}{c}\mathrm{Ca}[\mathrm{wt}-\%] \\
\text { dry mass }\end{array}$ & Mineralization & $\begin{array}{l}\text { Soft-tissue } \\
\text { preservation }\end{array}$ \\
\hline Procambarus fallax f. virginalis & This study & 1.30 & 0.01 & yes & yes \\
\hline Pomatoceras lamarckii eggs & Gostling et al. (2008) & & & & yes \\
\hline Haliotis asinina eggs & Gostling et al. (2008) & & & & yes \\
\hline Crassostrea gigas eggs & Gostling et al. (2008) & & & & yes \\
\hline Herdmania momus eggs & Gostling et al. (2008) & & & & yes \\
\hline Heliocidaris erythrogramma eggs & Raff et al. (2006) & & & & yes \\
\hline Homarus gammarus eggs & Martin et al. (2005) & 1.08 & 0.17 & yes & n.d. \\
\hline Limulus polyphemus eggs & Martin et al. (2005) & 0.32 & 0.21 & no & n.d. \\
\hline Nephrops norvegicus eggs & Martin et al. (2005) & 1.13 & 0.10 & yes & n.d. \\
\hline Palaemon elegans and eggs & Briggs and Kear (1994) & 0.67 & 7.90 & yes & yes* \\
\hline
\end{tabular}

* Soft-tissue preservation was mainly studied on the shrimp itself.

In contrast fresh crayfish eggs exposed to excess $\mathrm{CaCO}_{3}$ (experiments E1b, E2b, E3 and E4; Table 1) in air or $\mathrm{N}_{2}$ atmosphere, were preserved over several weeks. However, they only partially retained their original spherical shape (Fig. 1di). Collapse structures of the outer membrane were observed at least on one side. Commonly, polygonal ridges formed, which we interpret as shrinkage patterns, resulting from atrophy of the internal body. Subtle mineralization of finegrained flaky crystals, mostly along these polygonal structures, was evident after six days. The addition of activated carbon (experiment E3; Table 1) did not affect the tendency to mineralization. After two weeks, crystal envelopes covered the complete egg surface. In places, dense crystal accumulations up to $150 \mu \mathrm{m}$ in diameter formed (Fig. 1i). The SEM X-ray mappings highlight the post-experimental distribution of $\mathrm{P}$ and $\mathrm{Ca}$ with clear enrichment of these elements in surface crystallites (Fig. 4a, d).

Crayfish eggs that were heated prior to embedding (experiments E6 and E7; Table 1), exhibit complete preservation of the spherical morphology and complete mineralization of the outer membrane after one week (Fig. 1j-1; Fig. 5a, b). After one to three weeks, the crystal layer grew in places to a thickness of approximately $20 \mu \mathrm{m}$ (Fig. 6b) to $70 \mu \mathrm{m}$ (Fig. 6n). Xray maps of the entire specimens (Fig. 4b, c, e, f) show that the crystallites are composed of $\mathrm{P}$ - and Ca-bearing phases. High-resolution BSE images on these sections furthermore reveal an intergrowth of calcite (slightly higher white contrast) and brushite (Fig. 6a-o), which is verified by EDX analyses. The yolk and embryonic tissue (et) show a lower contrast with a regular pattern of pores (dark grey; yolk - bigger pores; et - small tiny pores; well visible in Fig. 6e, i, m) due to evaporation of the impregnation material Technovit ${ }^{\circledR}$. The outer embedding resin shows a more irregular shrinking pattern (Fig. 6a, e, i, m).

The mineralization mimics the initial $\mathrm{P}$ concentration in the untreated egg (Fig. 3b). It is highest in the germ area (Fig. 6e, g, m, n) and continuous in the endochorional en- velope (Fig. 6a, i, j), where it is also more intense at some localized areas (Fig. 6a, b). The calcite is fine-grained with a crystal size of approximately $300-400 \mathrm{~nm}$, brushite forms elongated prismatic crystals up to 5-10 $\mu \mathrm{m}$ long (Fig. 6c, d, o). Figure 6d is an SEM image slightly tilted from the plain of the section and shows the rather porous structure of the mineralization. Incipient mineralization of the inner organic tissue (within the embryonic tissue and yolk) was also observed. This can be seen clearly for the embryonic tissue of the germ area in Fig. 6j-1, and for the yolk in Fig. $6 \mathrm{f}-\mathrm{h}$.

Stained histological sections showed that the embryonic tissues of the embryo, i.e. various cell types and components, e.g. the cell nuclei, the segmented caudal papillae, and muscle cells were exceptionally well preserved after two and three weeks, respectively (Fig. 7a-d). The organic tissue of the endochorional envelope was not preserved. Instead, a fine-grained crystal rind completely covered the outer surface of the embryo replicating the endochorional envelope.

$\mathrm{X}$-ray diffraction and Rietveld refinement on the embedding medium and on surface crystallites of the mineralized layer of crayfish eggs of experimental series E7 confirmed the occurrence of brushite and calcite in approximately equal proportions. The measured ratio of brushite to calcite of the crystallites was 55:45 and 62:38 (in wt.-\%) in experiment 7.2 and 7.3, respectively (Table 2). However, the refinement of XRD data obtained from sample material of experiment E7.3 proved to be difficult, because the Durbin Watson factor (DW) and $\chi^{2}$ (Table 2) were unsatisfactory and the background values of the X-ray spectra were elevated. The ambiguous results of the Rietveld refinement might also reflect the poor crystallinity of the sampled material (see Briggs and Kear, 1993b). However, visual estimations of the BSE images in 2-D-sections indicate the occurrence of brushite and calcite in approximately similar amounts. 

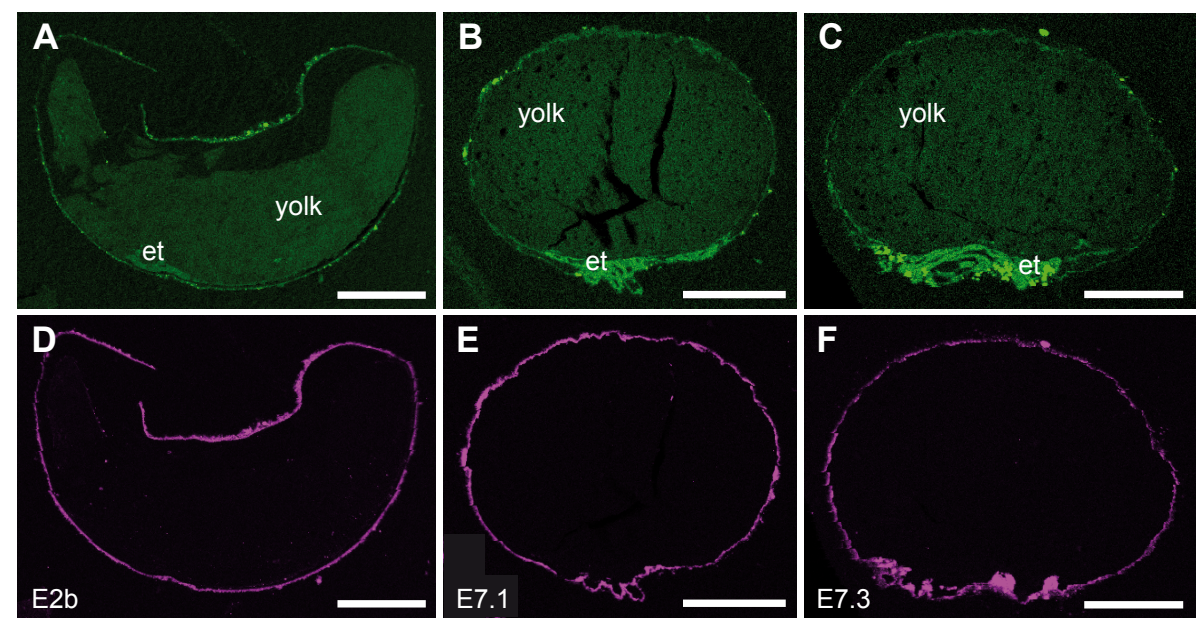

Fig. 4. Post-experimental distribution of $\mathrm{P}$ and $\mathrm{Ca}$ of sliced crayfish eggs. X-ray mappings of (A)-(C) $\mathrm{P}$ and (D)-(F) Ca highlight both the degree of morphology preservation and of continuous brushite and calcite mineralization (scale bar: $400 \mu \mathrm{m}$; E2b, E7.1, etc. = experiment number; et = embryonic tissue of the germ area).
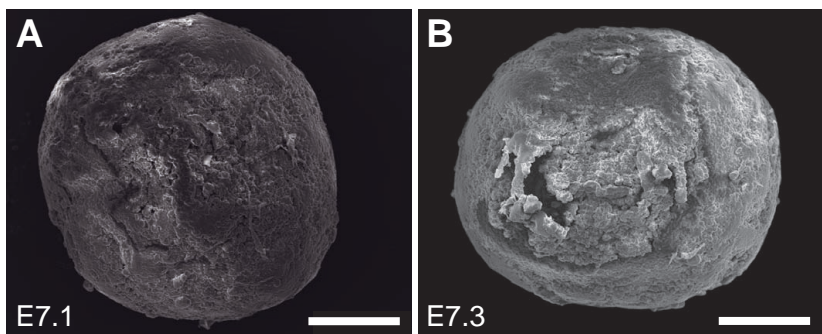

Fig. 5. SEM images of pre-heated crayfish eggs of E7.1 and E7.3 incubated under the same conditions. (A) After 1 week. (B) After 3 weeks. Complete preservation of the spherical morphology is evident and continuous mineralization occurs as fine-grained crystallites (scale bar: $400 \mu \mathrm{m}$ ).

\section{Discussion}

\subsection{Mineralization}

Our experiments show that the outer surface of crayfish eggs can be mineralized within one or two weeks under laboratory conditions in a manner that retains morphological detail similar to that preserved in fossil metazoan eggs (cf. Fig. 1). This finding holds true for all experiments applying the excess $\mathrm{CaCO}_{3}$ medium. A lack of mineralization and rapid decomposition of crayfish eggs was only observed in treatments with excess phosphoric acid, independent of the redox conditions. In this case crayfish eggs rapidly degrade through the process of autolysis, an internal cell destruction process caused by endogenous enzymes resulting in the coalescence of pigments and internal lipids or proteins, and finally the breakup of the endochorional envelope.

The crayfish eggs in our experiments became mineralized by a mixture of fine-grained brushite and calcite. Mineraliza- tion preferentially occurs where the initial $\mathrm{P}$ concentration in the egg is highest, i.e. around the embryonic germ area and along the envelope. The decomposing organic material liberates $\mathrm{P}$, which produces the highest local oversaturation where mineralization starts.

Preferred calcium phosphate precipitation over calcium carbonate was previously reported for laboratorymineralized body tissue of decapod crustaceans (Briggs and Kear, 1993a, 1994; Sagemann et al., 1999) as well as for fossil specimens (Bengtson and Zhao, 1997; Steiner et al., 2004a). Our phosphate to carbonate ratios and the ratios of laboratory-mineralized body tissue of decapod crustaceans were higher than the ratio obtained for previous laboratorymineralized eggs of decapod crustaceans. Initially, laboratory mineralization of metazoan eggs had been thought to be closely associated with closed-system conditions and the presence of the decaying mother animal carrying the egg mass (Briggs and Kear, 1993a). In this case, decomposition of Palaemon elegans occurred over a period of up to 25 weeks and the organism itself acted as the source of phosphate. Mineralization of the body tissue and the eggs occurred within a few weeks, either as pure calcium carbonate or a mix of calcium carbonate and phosphate. The eggs were, however, less mineralized than the other tissue and with a much lower phosphate-carbonate ratio (Briggs and Kear, 1993a). Whether changes in $\mathrm{pH}$, the concentration of $\mathrm{P}$ or a combination of both caused the observed differences in Palaemon elegans, however, remained unclear. Partial mineralization was also described for decay experiments on invertebrate eggs of the European and Norwegian lobsters, Homarus gammarus and Nephrops norvegicus (Martin et al., 2005), in which mineralization of eggs has been closely associated with bacteria generating anoxic conditions and reduced $\mathrm{pH}$. Mineralization of eggs occurred most commonly 

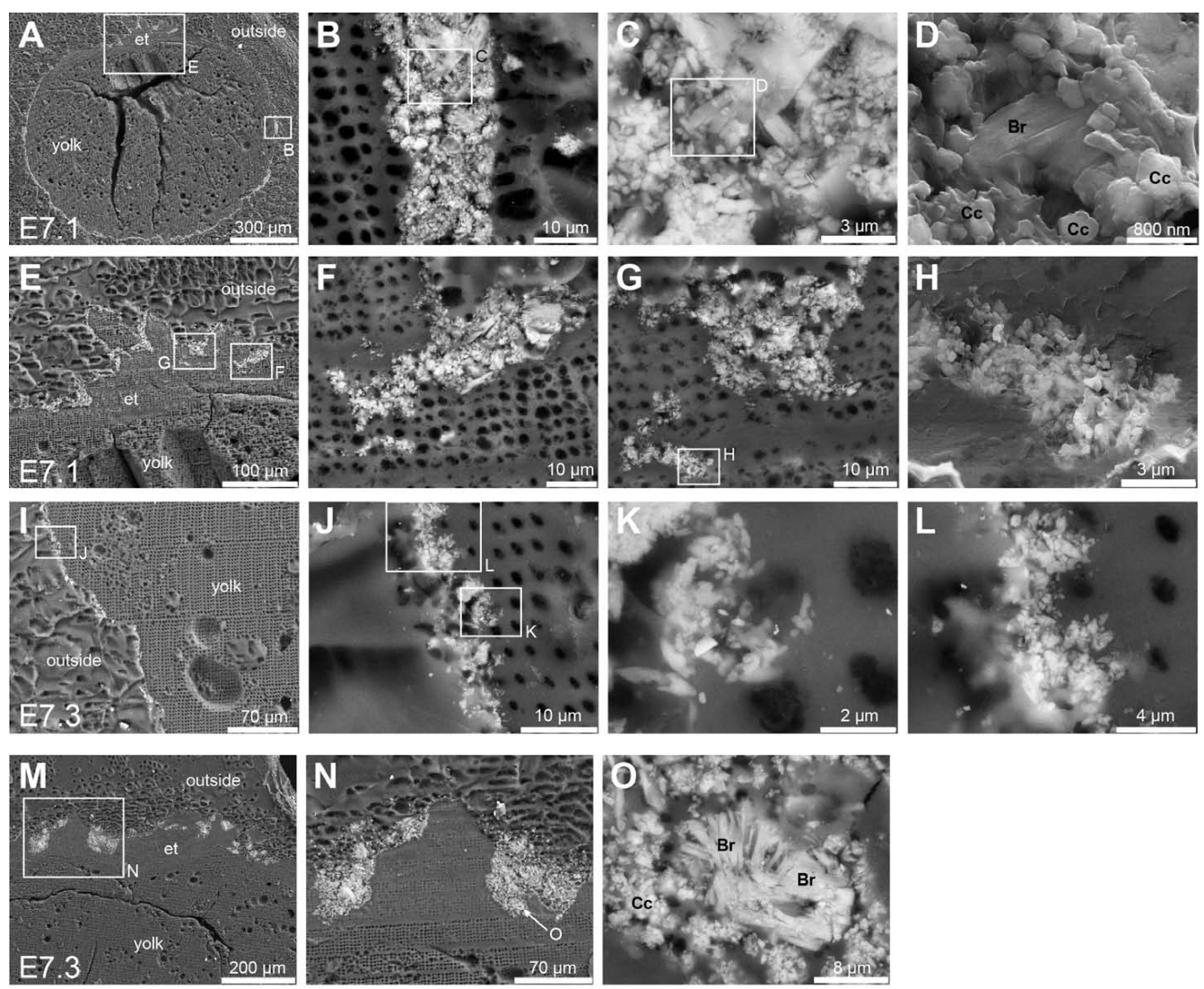

Fig. 6. (A)-(O) Backscattered electron (BSE) images and close-up views ( $\mathbf{D}$ and $\mathbf{H}$ as secondary electron images) of sliced post-experimental eggs from experiments E7.1 and E7.3 illustrating crystal texture, size and distribution of the mineralization around and within the mineralized embryos (for further details see text; $\mathrm{Br}=$ brushite; $\mathrm{Cc}=$ calcite; et = embryonic tissue of the germ area).

as calcium carbonate, or as a mixture of calcium carbonate and calcium phosphate. The only study reporting complete mineralization of the egg surface was performed on $\mathrm{H}$. gammarus, where eggs were decomposed in artificial seawater mixed with sediment over one month under anoxic conditions (Martin et al., 2003). In this experiment, the eggs were encrusted on the outside of the preserved egg envelope with a $50 \mu \mathrm{m}$ thick layer of mostly amorphous calcium carbonate and mineralized bacteria, with the latter result providing further evidence that bacteria may promote mineralization. Replicate experiments, with the same or modified parameters (e.g. egg mass, volume of artificial seawater, various additives), however, did not show complete surface mineralization with reasons for the observed variability in mineralization between treatments being unidentified.

\subsection{Preservation of organic tissue}

Histological sections of treated crayfish eggs showed exceptional preservation of the embryonic tissue after the experiment. Our study confirms results of other taphonomic experiments demonstrating that the morphology of metazoan embryos could be well preserved during prolonged periods for mineralization (Raff et al., 2006; Gostling et al., 2008). They particularly showed that reducing conditions are a key factor to prevent autolysis and preclude the activity of aerobic microbes.

Even though the embryonic tissue was well preserved, SEM images and histological sections indicate that the endochorional envelope of crayfish eggs showed degradation. A thin layer of fine-grained authigenic minerals replaced the endochorional envelope. This suggests that rapid decomposition of the endochorional envelope is accompanied by the rapid growth of authigenic minerals. Further evidence for this "replacement hypothesis" is provided by completely mineralized crayfish eggs showing different degrees of preservation, such as polygonal shrinkage patterns and collapse structures (Figs. 1d-i, 4a). Here, progressive mineralization must have occurred simultaneously to the decay of the endochorional envelope and the egg's internal content, thus preserving different stages of decay (after Gostling et al., 2008). This is commonly observed in the fossil record (cf. Fig. 1a-c). Several studies on fossil metazoan eggs and embryos have shown that their organic envelopes were not originally preserved, but that their original composition and structure was altered diagenetically by phosphatic replacement or 

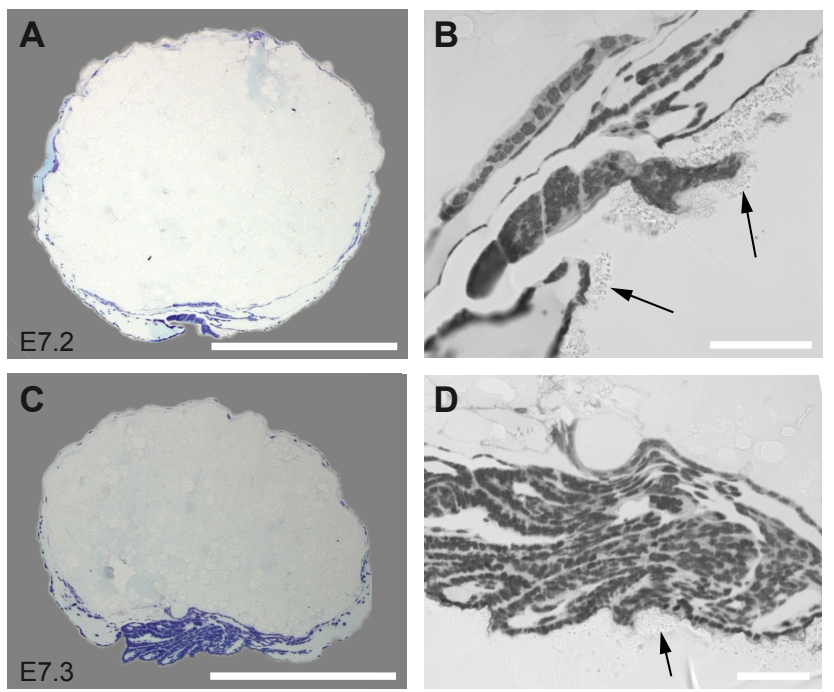

Fig. 7. Histological sections of mineralized pre-heated crayfish eggs showing preservation of embryonic tissue. (A), (B) After two weeks, experiment E7.2. (C), (D) After three weeks, experiment E7.3. Various cell types and components (e.g. cell nuclei of the segmented caudal papillae) are exceptionally well preserved and fine-grained brushite and calcite crystals (arrows) completely replicate the degraded endochorional envelope (Scale bars: $\mathbf{A}$ and $\mathbf{C}=500 \mu \mathrm{m} ; \mathbf{B}$ and $\mathbf{D}=50 \mu \mathrm{m})$.

encrustation of the envelope (Steiner et al., 2004a). Particularly, the detailed petrographic and geochemical studies on some organic-walled microfossils of the Doushantuo fossil Lagerstätte reported that phosphatization was an early diagenetic process in shallow burial depth, which occurred after rapid burial of the microorganisms and prior to the total decay of the organic matter and intergranular compaction ( $\mathrm{Hu}-$ bert et al., 2005). All findings thus suggest that the mechanisms of decay and mineral replacement were likely similar in both this study and the fossil material.

Only incipient mineralization was observed in the interior of the eggs, resembling results of similar experiments using eggs of Homarus gammarus (Martin et al., 2003). There are at least two possible explanations for this phenomenon: The newly formed mineral layer may either have acted as a barrier to microbial degradation of the internal cellular material or the dense structure of the yolk slowed or prevented the migration of substances necessary for mineralization. This "hollow egg" phenomenon is also known from Ediacaran and Cambrian fossil eggs (cf. Fig. 2; Steiner et al., 2004b).

\subsection{Preservation of the spherical egg-morphology}

Our experiments show that initial pre-heating of the crayfish eggs can stabilize their spherical morphology (Figs. 1j$1,5 \mathrm{a}-\mathrm{b})$. This is achieved both by denaturizing of the yolk and the embryonic tissue, and through prevention of internal decay, creating a stable template for mineralization. This result stands in marked contrast to the observations of all non-heated experiments, in which complete mineralization occurred but the original spherical shape was largely destroyed. We therefore hypothesize that the supply of heat, e.g. through the proximity of hot springs or a hydrothermal vent system, might have governed the preservation and fossilization of yolk-bearing eggs, embryos, larvae and small animals. However, heating is not a prerequisite for preservation, because spherically-preserved eggs and embryos are rare in the fossil record, whereas most fossils show collapsed structures (Figs. 1a-c; 2b). If eggs and embryos are preserved at all in Cambrian rock sequences at best only $9.5 \%$ (own observation) indicate a pristine external preservation without collapse structures.

\section{Conclusions}

Our laboratory phosphatization experiments show that complete surface mineralization of crayfish eggs, which were exposed to an inorganic two-component system consisting of calcite $+\mathrm{H}_{3} \mathrm{PO}_{4}$, may occur under anoxic conditions after one or two weeks, producing different grades of preservation in a manner similar to those described from the fossil record. While we found exceptional preservation of embryonic tissue at the cellular and morphological level after the time of the experiment, the endochorional envelope was not preserved, but was replicated by a thin rind of fine-grained brushite and calcite. This indicates a close link between rapid anaerobic decay of the endochorional envelope and mineral authigenesis, possibly microbially mediated. Pre-heating of the crayfish eggs stabilized the egg's spherical shape without changing the environment so that endochorional decay and mineralization could occur. Our reductionist phosphatization experiments provide further insights on the processes and conditions that might lead to exceptional egg and embryo fossilization, notably those at the PrecambrianCambrian transition.

Acknowledgements. This work is a contribution to the SinoGerman research group FOR 736 funded by the German Science Foundation grants FR 557/22-1 and HI 1553/1-2 to G. Franz and D. Hippler. We thank R. Mbacke (HU Berlin) for assistance in the laboratory, F. Lucassen (TU Berlin-GFZ Potsdam) for elemental analyses of the untreated embryos, and J. Nissen and U. Gernert (TU Berlin) for SEM images. M. Gottschalk, A. Watenphul (GFZ Potsdam) and C. Wolff (HU Berlin) are kindly acknowledged for providing XRD analyses and crayfish eggs, respectively. We also thank Wolfgang Kiessling for editorial handling, and two anonymous reviewers for their supportive and constructive comments.

Edited by: W. Kiessling 


\section{References}

Alwes, F. and Scholtz, G.: Stages and other aspects of the embryology of the parthenogenetic Marmorkrebs (Decapoda, Reptanis, Astacida), Dev. Genes Evol., 216, 169-184, 2006.

Bailey, J. V., Joye, S. B., Kalanetra, K. M., Flood, B. E., and Corsetti, F. A.: Evidence of giant sulphur bacteria in Neoproterozoic phosphorites, Nature, 445, 198-201, 2007a.

Bailey, J. V., Joye, S. B., Kalanetra, K. M., Flood, B. E., and Corsetti, F. A.: Reply, Nature, 446, E10, 2007b.

Bengtson, S. and Zhao, Y.: Fossilized metazoan embryos from the earliest Cambrian, Science, 277, 1645-1648, 1997.

Briggs, D. E. G.: Experimental taphonomy, Palaios, 10, 539-550, 1995.

Briggs, D. E. G.: The role of decay and mineralization in the preservation of soft-bodied fossils, Annu. Rev. Earth Planet. Sci., 31, 275-301, 2003.

Briggs, D. E. G. and Kear, A. J.: Fossilization of soft tissue in the laboratory, Science, 259, 1439-1442, 1993a.

Briggs, D. E. G. and Kear, A. J.: Decay and preservation of polychaetes: taphonomic thresholds in soft-bodied organisms, Paleobiology, 19, 107-135, 1993b.

Briggs, D. E. G. and Kear, A. J.: Decay and mineralization of shrimps, Palaios, 9, 431-456, 1994.

Briggs, D. E. G. and Wilby, P. R.: The role of the calcium carbonatecalcium phosphate switch in the mineralization of soft-bodied fossils, J. Geol. Soc. London, 153, 665-668, 1996.

Chen, J.-Y., Braun, A., Waloszek, D., and Qingqiang, P.: A Lower Cambrian yolk pyramid embryos from Southern Shaanxi, China, Progr. Nat. Sc., 14, 167-172, 2004.

Cheung, T. S.: The development of egg-membranes and egg attachment in the shore crab, Carcinus maenas, and some related decapods, J. Mar. Biol. Ass. UK, 46, 373-400, 1966.

Condon, D., Zhu, M., Bowring, S., Wang, W., Yang, A., and Jin, Y.: U-Pb ages from the Neoproterozoic Doushantuo Formation, China, Science, 308, 95-98, 2005.

Dong, X.-P., Bengtson, S., Gostlings, N. J., Cunningham, J. A., Harvey, T. H. P., Kouchinsky, A., Val'kov, A. K., Repetski, J. E., Stampanoni, M., Marone, F., and Donoghue, P. C. J.: The anatomy, taphonomy, taxonomy and systematic affinity of Markuelia: Early Cambrian to early Ordovician scalidophorans, Palaeontology, 53, 1291-1314, 2010.

Donoghue, P. C. J.: Embryonic identy crisis, Nature, 445, 155-156, 2007.

Donoghue, P. C. J. and Dong, X.: Embryos and ancestors, pp. 8199, in: Evolving form and function: Fossils and development, edited by: Briggs, D. E. G., Yale Peabody Museum, New Haven, 288 p., 2005.

Donoghue, P. C. J., Kouchinsky, A., Waloszek, D., Bengtson, S., Dong, X., Val'kov, A. K., Cunningham, J. A., and Repetski, J. E.: Fossilized embryos are widespread but the record is temporally and taxonomically biased, Evol. Dev., 8, 232-238, 2006.

Dornbos, S. Q., Bottjer, D. J., Chen, J.-Y., Oliveri, P., Gao, F., and Li, C.-W.: Precambrian animal life: Taphonomy of phosphatized metazoan embryos from southwest China, Lethaia, 38, 101-109, 2005.

Gostling, N. J., Thomas, C., Greenwood, J. M., Dong, X., Bengtson, S., Raff, E. C., Raff, R. A., Degnan, B. M., Stampanoni, M., and Donoghue, P. C. J.: Deciphering the fossil record of early bilaterian embryonic development in light of experimental taphonomy,
Evol. Dev., 10, 339-349, 2008.

Gostling, N. J., Dong, X., and Donoghue, P. C. J.: Ontogeny and taphonomy: An experimental taphonomy study of the development of the brine shrimp Artemia salina, Palaeontology, 52, 169186, 2009.

Gottschalk, M., Najorka, J., and Andrut, M.: Structural and compositional characterization of synthetic $(\mathrm{Ca}, \mathrm{Sr})$-tremolite and $(\mathrm{Ca}$, Sr)-diopside solid solutions, Phys. Chem. Minerals, 25, 415-428, 1998.

Hubert, B., Alvaro, J. J., and Chen, J.-Y.: Microbially mediated phosphatization in the Neoproterozoic Doushantuo Lagerstätte, South China. Bull. Soc. Geol. Fr., 176, 355-361, 2005.

Huldtgren, T., Cunningham, J. A., Yin, C., Stampanoni, M., Marone, F., Donoghue, P. C. J., and Bengtson, S.: Fossilized nuclei and germination structures identify Ediacaran "animal embryos" as encysting protists, Science, 334, 1696-1699, 2011.

Li, C.-W., Chen, J.-Y., and Hua, T.-E.: Precambrian sponges with cellular structures, Science, 279, 879-882, 1998.

Liu, Y., Li, Y., Shao, T., Zhu, Z., Yu, B., Wang, Z., Zhang, W., and Li, R.: Phosphatized Punctatus with mouthparts and its embryo fossils from the Lower Cambrian of Ningqiang, south Shaanxi, China, Frontiers of Earth Science in China, 1, 1-11, 2007.

Martin, D., Briggs, D. E. G., and Parkes, R. J.: Experimental mineralization of invertebrate eggs and the preservation of Neoproterozoic embryos, Geology, 31, 39-42, 2003.

Martin, D., Briggs, D. E. G., and Parkes, R. J.: Experimental attachment of sediment particles to invertebrate eggs and the preservation of soft-bodied fossils, J. Geol. Soc. London, 161, 735-738, 2004.

Martin, D., Briggs, D. E. G., and Parkes, R. J.: Decay and mineralization of invertebrate eggs, Palaois, 20, 562-572, 2005.

Martin, P., Kohlmann, K., and Scholtz, G.: The parthenogenetic Marmorkrebs (marbled crayfish) produces genetically uniform offspring, Naturwissenschaften, 94, 843-846, 2007.

Martin, P., Dorn, N. J., Kawai, T., van der Heiden, C., and Scholtz, G.: The enigmatic Marmorkrebs (Marbled crayfish) is the parthenogenetic form of Procambarus fallax (Hagen, 1870), Contrib. Zool., 79, 107-118, 2010.

Peterson, K. J., McPeek, M. A., and Evans, D. A. D.: Tempo and mode of early animal evolution: inferences from rocks, Hox, and molecular clocks, Paleobiology, 31, 36-55, 2005.

Peterson, K. J., Cotton, J. A., Gehling, J. G., and Pisani, D.: The Ediacaran emergence of bilaterians: congruence between the genetic and the geological fossil records, Philos. Trans. R. Soc. London B. Biol. Sci., 363, 1435-1443, 2008.

Raff, E. C., Villinski, J. T., Turner, F. R., Donoghue, P. C. J., and Raff, R. A.: Experimental taphonomy shows the feasibility of fossil embryos, Proc. Nat. Acad. Sci. USA, 103, 5846-5851, 2006.

Raff, E. C., Schollaert, K. L., Nelson, D. E., Donoghue, P. C. J., Thomas, C., Turner, F. R., Stein, B. D., Dong, X., Bengtson, S., Huldtgren, T., Stampanoni, M., Chongyu, Y., and Raff, R. A.: Embryo fossilization is a biological process mediated by microbial biofilms, Proc. Nat. Acad. Sci. USA, 105, 19360-19365, 2008.

Sagemann, J., Bale, S. J., Briggs, D. E. G., and Parkes, R. J.: Controls on the formation of authigenic minerals in association with decaying organic matter: an experimental approach, Geochim Cosmochim Acta, 63, 1083-1095, 1999. 
Scholtz, G., Braband, A., Tolley, L., Reimann, A., Mittmann, B., Lukhaup, C., Steuerwald, F., and Vogt, G.: Parthenogenesis in an outsider crayfish, Nature, 421, 806, 2003.

Steiner, M., Li, G., Qian, Y., and Zhu, M.: Lower Cambrian small shelly fossils of northern Sichuan and southern Shaanxi (China), and their biostratigraphic importance, Geobios, 37, 259-275, 2004a.

Steiner, M., Zhu, M., Li, G., Qian, Y., and Erdtmann, B. D.: New early Cambrian bilaterian embryos and larvae from China, Geology, 32, 833-836, 2004b.

Winnicki, A., Pawlos, D., Formicki, K., and Smietana, P.: On selected morphomechanical characteristics of signal crayfish (Pacifastacus leniusculus Dana) eggs during incubation, Bull. Fr. Pêche. Piscic., 372/373, 431-438, 2004.
Xiao, S. and Knoll, A. H.: Fossil preservation in the Neoproterozoic Doushantuo phosphorite Lagerstätte, South China, Lethaia, 32, 219-240, 1999.

Xiao, S., Zhang, Y., and Knoll, A. H.: Three-dimensional preservation of algae and animal embryos in a Neoproterozoic phosphorite, Nature, 391, 553-558, 1998.

Xiao, S., Yuan, X., and Knoll, A. H.: Eumetazoan fossils in terminal Proterozoic phosphorites? Proc. Nat. Acad. Sci. USA, 97, 13684-13689, 2000. 